\title{
Front Matter: Volume 11003
}

, "Front Matter: Volume 11003," Proc. SPIE 11003, Radar Sensor Technology XXIII, 1100301 (12 August 2019); doi: 10.1117/12.2537087

SPIE Event: SPIE Defense + Commercial Sensing, 2019, Baltimore, MD, United SPIE. States 


\title{
PROCEEDINGS OF SPIE
}

\section{Radar Sensor Technology XXIII}

\author{
Kenneth I. Ranney \\ Armin Doerry \\ Editors
}

15-17 April 2019

Baltimore, Maryland, United States

Sponsored and Published by

SPIE 
The papers in this volume were part of the technical conference cited on the cover and title page. Papers were selected and subject to review by the editors and conference program committee. Some conference presentations may not be available for publication. Additional papers and presentation recordings may be available online in the SPIE Digital Library at SPIEDigitalLibrary.org.

The papers reflect the work and thoughts of the authors and are published herein as submitted. The publisher is not responsible for the validity of the information or for any outcomes resulting from reliance thereon.

Please use the following format to cite material from these proceedings:

Author(s), "Title of Paper," in Radar Sensor Technology XXIII, edited by Kenneth I. Ranney, Armin Doerry, Proceedings of SPIE Vol. 11003 (SPIE, Bellingham, WA, 2019) Seven-digit Article CID Number.

ISSN: 0277-786X

ISSN: 1996-756X (electronic)

ISBN: 9781510626713

ISBN: 9781510626720 (electronic)

Published by

SPIE

P.O. Box 10, Bellingham, Washington 98227-0010 USA

Telephone +1 3606763290 (Pacific Time) · Fax +1 3606471445

SPIE.org

Copyright (c) 2019, Society of Photo-Optical Instrumentation Engineers.

Copying of material in this book for internal or personal use, or for the internal or personal use of specific clients, beyond the fair use provisions granted by the U.S. Copyright Law is authorized by SPIE subject to payment of copying fees. The Transactional Reporting Service base fee for this volume is $\$ 18.00$ per article (or portion thereof), which should be paid directly to the Copyright Clearance Center (CCC), 222 Rosewood Drive, Danvers, MA 01923. Payment may also be made electronically through CCC Online at copyright.com. Other copying for republication, resale, advertising or promotion, or any form of systematic or multiple reproduction of any material in this book is prohibited except with permission in writing from the publisher. The CCC fee code is 0277 $786 \mathrm{X} / 19 / \$ 18.00$.

Printed in the United States of America by Curran Associates, Inc., under license from SPIE.

Publication of record for individual papers is online in the SPIE Digital Library.

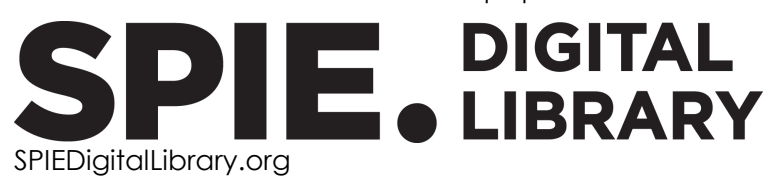

Paper Numbering: Proceedings of SPIE follow an e-First publication model. A unique citation identifier (CID) number is assigned to each article at the time of publication. Utilization of CIDs allows articles to be fully citable as soon as they are published online, and connects the same identifier to all online and print versions of the publication. SPIE uses a seven-digit CID article numbering system structured as follows:

- The first five digits correspond to the SPIE volume number.

- The last two digits indicate publication order within the volume using a Base 36 numbering system employing both numerals and letters. These two-number sets start with 00, 01, 02, 03, 04, 05, 06, 07, 08, 09, OA, OB ... 0Z, followed by 10-1Z, 20-2Z, etc. The CID Number appears on each page of the manuscript. 


\section{Contents}

$\begin{array}{ll}\text { vii } & \text { Authors } \\ \text { ix } & \text { Conference Committee }\end{array}$

\section{SYSTEMS I}

$1100303 \quad$ FM radio passive multistatic radar using data fusion [1 1003-2]

1100304 A comparison of ground-based and airborne SAR systems for the detection of landmines, UXO, and IEDs [11003-3]

1100305 Imaging of buried targets using UAV-based, ground penetrating, synthetic aperture radar [11003-4]

\section{SYSTEM DEVELOPMENT}

1100306 Investigation of airborne synthetic aperture radar parameters for buried target detection [11003-5]

1100307 Simultaneous multi-mission (SMM) in ground and airborne radars: system development tools and enabling technologies [1 1003-6]

1100308 Robust decision making method for adaptive ordered-statistics CFAR technique using information elasticity [1 1003-7]

1100309 Physical-model-aided antenna pattern calibration for flight inspection [1 1003-8]

$11003 \mathrm{OA}$ Cost function design for modeling information overload in radar systems [1 1003-9]

NON-LINEAR RADAR

$11003 \mathrm{OF}$ Harmonic nonlinear radar: from benchtop experimentation to short-range wireless data collection [11003-15]

$110030 G$ High resolution harmonic radar imaging for safety and security applications [1 1003-16]

POLARIZATION

$11003 \mathrm{OH} \quad$ Performance effect of unintended polarization on clutter attenuation [1 1003-17] 
$11003 \mathrm{Ol} \quad$ Empirical observations from analysis of coherency matrices of 4-look SIR-C data [11003-18]

NOISE RADAR

11003 OK A formulation of noise operators and their applications [1 1003-20]

11003 OL Kicked rotor quantum chaos (KRQC) for radar noise waveform design [1 1003-21]

11003 OM Design of spectrally adaptive noise radar waveforms [1 1003-22]

DOPPLER AND MICRO-DOPPLER

11003 ON On minimum detectable velocity [1 1003-23]

11003 OP Detection of vibrating objects in SAR images [1 1003-25]

$110030 Q \quad$ Abnormal gait detection and classification using micro-Doppler radar signatures [11003-26]

11003 OR Simulation of the dynamic radar cross section variations of a human emulator calibration target for through-wall and through-rubble radar [1 1003-27]

11003 OS Millimeter-wave radar micro-Doppler feature extraction of consumer drones and birds for target discrimination [1 1003-28]

\section{PROCESSING I: PARALLEL PROCESSING AND MACHINE LEARNING}

11003 OU A method for accurate, highly parallelizable SAR image reconstruction without interpolation [1 1003-29]

11003 OV Quantized wavelet scattering networks for signal classification [11003-31]

11003 OW Convergence analysis of the CNN algorithm in target recognition using SAR images [1 1003-32]

11003 0X Further investigation of the application of deep learning for electromagnetic simulation prediction [11003-33]

\section{SYSTEM HARDWARE}

11003 OY Total reliability of radar systems: incorporating component degradation effects in operational reliability [1 1003-34]

iv 
$1100310 \quad$ Non-cooperative emitter classification and localization with vector sensing and machine learning in indoor environments [1 1003-36]

1100311 Satellite radar interferometry using micro-retroreflective arrays [11003-37]

1100312 Challenges in very high resolution imaging of satellites and objects in space [1 1003-38]

1100314 Applications of the Aharonov Ansatz to antenna theory: Part III [1 1003-40]

\section{APPLICATIONS}

1100316 Application of microwave noiselets for nondestructive testing of unidirectional carbon fiber reinforced polymers [11003-42]

1100317 Electromagnetic response changes of unidirectional carbon fiber-reinforced polymer circuitanalog absorbers due to post-processing impact damage [1 1003-43]

$1100318 \quad$ Comparing stochastic and Markov decision process approaches for predicting radio frequency interference [11003-44]

PROCESSING II: WAVEFORM DESIGN

1100319 Channel-hopping blind rendezvous for cognitive radio networks using channel occupancy prediction [11003-45]

$110031 \mathrm{~A} \quad$ Modified transmitted reference technique for multi-resolution radar timing and synchronization [11003-46]

11003 1B Polynomial chirplet approach for frequency modulation signal separation and classification [11003-47]

11003 1C A compound Gaussian-based waveform design approach for enhanced target detection in multistatic radar imaging [1 1003-48]

MILLIMETRE WAVE RADAR: JOINT SESSION WITH CONFERENCES 10994 AND 11003

11003 ID Millimeter-wave airborne radar for learning and education (MARBLE): an undergraduate student mission [1 1003-49] 


\section{POSTER SESSION}

$11003 \mathrm{IE} \quad$ Analyzing receiver bandwidth for near-range ultra-wideband pulse compression imaging radar systems [1 1003-50]

11003 IF Radiometric calibration of range-Doppler radar data [1 1003-51]

11003 1G Implementation of practically realizable micro-Doppler experiment and real-time microDoppler feature extraction algorithm [1 1003-52]

$110031 \mathrm{H} \quad$ Design and analysis of the PLL-based synthesizer for UAV detection radar applications [11003-53]

$1100311 \quad$ Issues associated with radar applications on software defined radios [1 1003-54] 


\section{Authors}

Numbers in the index correspond to the last two digits of the seven-digit citation identifier (CID) article numbering system used in Proceedings of SPIE. The first five digits reflect the volume number. Base 36 numbering is employed for the last two digits and indicates the order of articles within the volume. Numbers start with 00, 01, 02, 03, 04, 05, 06, 07, 08, 09, OA, OB...0Z, followed by 10-1Z, 20-2Z, etc.

Addison, Stephen R., OK

Anger, S., 12

Atwood, Thomas, OP

Bähnemann, Rik, 04

Bajic, Ivan, OU

Bassett, Christopher, 07

Bickel, D. L., OH, ON

Bischeltsrieder, Florian, OG

Blount, Clay B., OX

Buehrer, R. Michael, 18

Burr, Ralf, 04

Dill, S., 12

Doerry, Armin W., OH, ON, OP, IF

Dogaru, Traian V., 05, 06

Dunkel, Ralf, OP

Dyer, John, 09, 1D

Fox, Maxine R., OV

Fusselman, Jakob, 1D

Gallagher, Kyle, 1 I

Geaga, Jorge V., Ol

Gedin, Kahlil R., 14

Gilliam, Matthew, 09, 1D

Gray, John E., OK, 14

Hall, Donald L., OQ, 10

Handel, Clark F., 03

Hayat, Majeed M., OP

Hedden, Abigail, 11

Heinzel, Andreas, 04, 0G

Homeyer, Cameron, ID

Idriss, Zacharie, 1C

Jendzurski, John R., OR

Jenkins, David M., 10, 1A

Jiroušek, Matthias, 0G, 12

Kelly, Colin D., 06, 1E

Kelly, Keith, 07

Kim, Taeyoung, OR

Kovarskiy, Jacob A., 18

Kozy, Mark, 18

Lee, Hua-Chin, $1 \mathrm{H}$

Lenzing, Erik H., 10

Li, Bing C., OL, 1B

Liao, DaHan, 05

Lipski, Michael V., 19

Liu, Andrew Z., 08

Martinez, Emilio, 11

Martone, Anthony F., 18

Mazzaro, Gregory J., OF

Moore, B. David, 11
Narayanan, Ram M., 03, 06, 08, OA, OM, OQ, OR,

OV, OY, 10, 16, 17, 18, 19, 1A, 1C, 1E

Navagato, Marc D., 16

Necsoiu, Marius, 11

O'Donnell, Joseph C., 17

Ou Yang, Liang-Yu, $1 \mathrm{G}$

Paulter, Nicholas G., OR

Peichl, Markus, 04, 0G, 12

Pérez, Francisco, OP

Phelan, Brian R., 05, 06, 1E

Pici, Caden J., OM

Price, Carey D., OX

Price, Stanton R., OX

Price, Steven R., OX

Qiao, Zhijun, OW

Rahman, Samiur, OS

Raj, Raghu G., OV, 1C

Rangaswamy, Muralidhar, 08, 0A

Ranney, Kenneth I., II

Ridder, Tyler D., OQ, OY

Riley, Elliot J., 17

Robertson, Duncan A., OS

Salazar Cerreno, Jorge, 07

Santhanam, Balu, OP

Schartel, Markus, 04

Schreiber, Eric, 04, 0G

Sherbondy, Kelly D., 06, OF, 18, 1E

Singerman, Paul G., OA

Thornton, Charles, 18

Tsai, Ming-Fa, $1 \mathrm{G}$

Tsao, Ya-Lan, $1 \mathrm{H}$

Waldschmidt, Christian, 04

Wang, Chao-Shiun, $1 \mathrm{H}$

Young, Jason R., IA

Zhang, Yan Rockee, 07, 09, 1D

Zou, Ligang, OW 
Proc. of SPIE Vol. 11003 1100301-8 Downloaded From: https://www.spiedigitallibrary.org/conference-proceedings-of-spie on 26 Apr 2023
Terms of Use: https://www.spiedigitallibrary.org/terms-of-use 


\title{
Conference Committee
}

\author{
Symposium Chairs
}

Jay Kumler, JENOPTIK Optical Systems, LLC (United States)

Ruth L. Moser, Air Force Research Laboratory (United States)

Symposium Co-chair

John M. Pellegrino, Georgia Institute of Technology (United States)

\section{Conference Chairs}

Kenneth I. Ranney, U.S. Army Research Laboratory (United States)

Armin Doerry, Sandia National Laboratories (United States)

\section{Conference Program Committee}

Fauzia Ahmad, Temple University (United States)

Moeness G. Amin, Villanova University (United States)

Joseph C. Deroba, U.S. Army CERDEC Intelligence and Information

Warfare Directorate (United States)

Mark Govoni, U.S. Army Research Laboratory (United States)

John E. Gray, Naval Surface Warfare Center Dahlgren Division (United States)

Majeed M. Hayat, Marquette University (United States)

Chandra Kambhamettu, University of Delaware (United States)

Seong-Hwoon Kim, L3 Technologies, Inc. (United States)

Marco O. Lanzagorta, U.S. Naval Research Laboratory (United States)

Bing C. Li, Lockheed Martin Systems Integration-Owego (United States)

Changzhi Li, Texas Tech University (United States)

Jenshan Lin, University of Florida (United States)

Robert Linnehan, General Atomics Aeronautical Systems, Inc. (United States)

Ronald D. Lipps, U.S. Naval Research Laboratory (United States)

David G. Long, Brigham Young University (United States)

Neeraj Magotra, Western New England University (United States)

Anthony F. Martone, U.S. Army Research Laboratory (United States)

Gregory J. Mazzaro, The Citadel-The Military College of South Carolina (United States)

Ram M. Narayanan, The Pennsylvania State University (United States)

Marius Necsoiu, Southwest Research Institute (United States)

Lam H. Nguyen, U.S. Army Research Laboratory (United States)

Hector A. Ochoa, The University of Texas at Tyler (United States) 
Thomas J. Pizzillo, U.S. Naval Research Laboratory (United States)

Zhijun G. Qiao, The University of Texas-Pan American (United States)

Ann Marie Raynal, Sandia National Laboratories (United States)

Jerry Silvious, U.S. Army Research Laboratory (United States)

David Tahmoush, U.S. Naval Research Laboratory (United States)

Russell Vela, Air Force Research Laboratory (United States)

Frank Yakos, Consultant (United States)

Yan Rockee Zhang, The University of Oklahoma (United States)

Ruolin Zhou, Western New England University (United States)

\section{Session Chairs}

1 Systems I

Lam H. Nguyen, U.S. Army Research Laboratory (United States)

2 System Development

Gregory J. Mazzaro, The Citadel-The Military College of South Carolina (United States)

3 Radar Research at Government Labs

Armin W. Doerry, Sandia National Laboratories (United States)

Kenneth I. Ranney, U.S. Army Research Laboratory (United States)

$4 \quad$ Non-Linear Radar

Brian R. Phelan, U.S. Army Research Laboratory (United States)

5 Polarization

Brian R. Phelan, U.S. Army Research Laboratory (United States)

6 The History of Noise

John E. Gray, Naval Surface Warfare Center Dahlgren Division (United States)

$7 \quad$ Noise Radar

Ram M. Narayanan, The Pennsylvania State University (United States)

8 Doppler and Micro-Doppler

Ann Marie Raynal, Sandia National Laboratories (United States)

9 Processing I: Parallel Processing and Machine Learning

Yan Rockee Zhang, The University of Oklahoma (United States)

10 System Hardware

Seong-Hwoon Kim, L3 Technologies, Inc. (United States) 
11 Systems II

Bing C. Li, Lockheed Martin Systems Integration-Owego (United States)

12 Applications

Seong-Hwoon Kim, L3 Technologies, Inc. (United States)

13 Processing II: Waveform Design

Ram M. Narayanan, The Pennsylvania State University (United States)

14 Millimetre Wave Radar: Joint Session with Conferences 10994 and 11003

David A. Wikner, U.S. Army Research Laboratory (United States) 
Proc. of SPIE Vol. 11003 1100301-12

Downloaded From: https://www.spiedigitallibrary.org/conference-proceedings-of-spie on 26 Apr 2023 Terms of Use: https://www.spiedigitallibrary.org/terms-of-use 